\title{
The origins of co-operation in Ireland
}

The establishment of the Irish Agricultural Organisation Society (IAOS) in Dublin in April 1894 marked a milestone in the emergence of the modern Irish nationstate. The new society offered leadership to the co-operative societies formed over the previous five years that aimed to improve the state of Irish agriculture. Presided over by Horace Plunkett, the Anglo-Irish agricultural reformer and Unionist MP for South Dublin, the IAOS aimed to inject a new spirit of vitality and innovation across rural Ireland. Plunkett outlined a hopeful vision for the IAOS that saw people of all political and religious stripes united behind a project to promote 'the welfare of the agricultural classes'. Plunkett's appeal for crosssocietal support to spread the principle of co-operation stood out in a context of fractious debates about what direction Ireland's political future should take. As someone who studied the condition of Irish agriculture, Plunkett concluded that farmers worked within an exploitative system. Farmers bought too dear and sold too cheap; transport costs remained too high; inadequate credit provision existed; and an under-utilisation of resources saw farmers fall short of their potential. The Irish situation stood in sharp contrast to other countries where farming communities overcame some of these challenges. However, he continued, wherever such progress has been made, the means by which the improvement has been effected has been the same, namely, organisation'. ${ }^{1}$

If, as James Scott has argued, the condition of modernity is the organisation of knowledge and resources to overcome economic and social problems, such as the production of food, then the IAOS can claim to have left a long-lasting legacy in modern Ireland. Modernising projects, so frequently associated with processes of urbanisation, can equally apply to developmental strategies in the rural sphere and agriculture. ${ }^{2}$ The originality of the IAOS's intervention resided in its efforts to organise the constituents of rural society around a network of co-operative creameries, credit societies and agricultural societies. The principle of co-operation underpinned and unified the new rural movement. Yet despite the emphasis on cross-communal support and encouragement of active participation among its supporters, perhaps because of it, it provoked huge controversy upon its introduction to rural Ireland. 
The aim of this chapter is to establish how the concept of co-operation applied to Ireland at the end of the nineteenth century. Before examining the extent to which farmers embraced co-operative ideas, and the challenges placed in the way of this radical new form of economic organisation, it is necessary to outline the social, economic and political conditions under which co-operative activists promoted their ideas among Irish farmers. Ireland experienced tumultuous political and social change in the second half of nineteenth century because of devastating famine. The co-operative movement's introduction at the end of the nineteenth century represented a rigorous attempt to deal with the worst effects of rural instability. But the introduction of co-operative ideas also pointed to the significance of the transnational intellectual currents that shaped the state of modern Ireland.

As well as outlining general conditions in Ireland, it is important to understand how Plunkett and others arrived at the conclusion that co-operative principles would best serve Irish economic interests. Accordingly, the second object of this chapter is to locate Irish co-operation within this wider milieu. Enthusiasts for the co-operative idea studied the example of co-operative experts at work in countries such as Britain, Germany and Denmark. The existence of a large multinational, consumer-oriented co-operative organisation in Britain proved to be influential in deciding the form which mainstream co-operation in Ireland took. The final section of the chapter examines how the early efforts of IAOS organisers challenged a British model of co-operation. The tension generated between the Irish and British movements is analysed and shown to define the Irish co-operative project by the early twentieth century. The challenge presented by a consumer-oriented movement forced the IAOS to emphasise its own producer credentials. This conflict helped define Irish economic identity as one that revolved around agricultural producers. This battle to promote one conception of cooperation over another helped set the terms of Irish economic development for decades.

\section{Rural Ireland in the late nineteenth century}

Horace Plunkett presented a pessimistic portrait of the countryside in his book Ireland in the New Century. He viewed the source of social and political grievance within the country primarily as economic in nature. High levels of emigration offered a chief symptom of both a 'low national vitality' and what he termed the 'problem of rural life'. To reverse this process he argued that to 'keep the people at home we have got to construct a national life with ... a secure basis of physical comfort and decency. This life must have a character, a dignity, an outlook of its own. ${ }^{3}$ Plunkett played many roles throughout his life - agricultural reformer, parliamentarian and philanthropist - but each venture upon which he embarked attempted to answer the question about how one might construct a new type of national life. It was in his role as founder and leader of Ireland's 
co-operative movement that he achieved his greatest degree of success in resolving this issue.

Plunkett's promotion of the co-operative principle offered a response to what he understood as a deep crisis of Irish agriculture, one that only accelerated throughout the nineteenth century. Competition from large-scale farming outfits in America and more organised competitors on the continent stressed the need for reform. Co-operative societies acted as agents of 'social and economic progress' by creating bonds of mutuality and cohesion between farmers and prepared them for the great struggle of international competition. ${ }^{4}$ The movement's efforts to revitalise rural life happened at the end of a century in which a devastating famine fundamentally restructured social, economic and demographic conditions. ${ }^{5}$ The Great Famine of 1845-51 resulted in the death of an estimated 1.1 million people and the emigration of some 2.1 million in the decade after $1845 .^{6}$ Three important features of rural life crystallised in the aftermath. First, high levels of emigration out of Ireland, particularly from rural regions, became a normalised feature of everyday life. As Enda Delaney highlighted, almost as many people born in Ireland lived outside the country as in it by the end of the nineteenth century. ${ }^{7}$ The impact of this movement of people profoundly shaped Irish society in many ways. Emigration provided a recurring source of anxiety throughout the nineteenth and twentieth centuries and posed a series of social, economic and moral questions for Ireland's political and spiritual leaders. ${ }^{8}$

The longer-term economic trajectory saw increased pressures placed on Ireland's farmers, typified by an agricultural depression in the early 1880s. The value of agricultural output in 1886 stood at 64 per cent of its 1876 value and, meanwhile, international competition only increased.' The timing of this depression compounded another problem for Irish farmers engaged in dairy production. For much of the nineteenth century, Ireland enjoyed a position as one of the preeminent suppliers of butter to Britain. Butter production took place within the home, by women who worked the product by hand. ${ }^{10}$ This butter would be sold to merchants who supplied one of the markets in Ireland, or sent on to Britain where it formed an important source of nutrition for the industrial workforce. The invention of the creamery separator in the late 1870s revolutionised the butter industry. Before this invention, producers placed milk in containers and waited for the cream required for the manufacturing process to separate gradually. The mechanical creamery separator accelerated the separation process and extracted a higher proportion of cream from the milk.

The swift diffusion of the new separation technology in Denmark gave dairy farmers in that country a distinct competitive advantage over their Irish counterparts. ${ }^{11}$ Throughout the 1880 s Irish butter producers lost their pre-eminent position in the British marketplace to their better-organised Danish rivals. The widespread establishment of co-operatively organised creameries placed ownership over the separator in the hands of many Danish farmers. ${ }^{12}$ Reform-minded 
individuals such as Plunkett noted that the diffusion of new technology and the manufacture of an improved product occurred through co-operative endeavour.

A third feature saw the persistence of rural unrest that revolved around the vexed question of land ownership and what constituted a fair rent for farmers. A series of legislative land reforms from 1870 onwards sought to achieve the gradual transfer of land ownership from the landlords to tenant farmers. A series of poor harvests throughout the 1870s saw an increase in rural unrest and violence. The establishment of the Land League by Michael Davitt in 1879 and the election of Charles Stewart Parnell, leader of the Irish Parliamentary Party (IPP), as President of the League saw a political campaign for land reform aligned to a social movement that promoted agitation. The Land League's demands the 'Three Fs' - fair rent, fixity of tenure and fair sale - shaped the terms of Gladstone's 1881 Land Act. The 1881 Land Act formed the Liberal Government's response to the rural discontent that was the Land War. The Act established a Land Court empowered to control rents, with the result that over the next two decades almost two-thirds of land occupiers experienced an average rent reduction of 22 per cent. ${ }^{13}$ Despite legislative changes to land ownership and tenant rights imposed by Gladstone's Government, a sense of unfinished business around the issue remained in place. This incomplete settlement of the land question at the end of the nineteenth century ushered in a temporary cessation of rural violence that allowed the co-operative movement to flourish. However, practices of land redistribution continued long into the twentieth century and remained an emotive political issue beyond independence. ${ }^{14}$

Plunkett believed that 'the spread of agricultural co-operation through voluntary associations' was required to overcome practical problems that affected Irish farming's international reputation and also offered a way to more effectively exploit national resources. He argued that co-operative societies represented an 'agency of social and economic progress' without which:

[s]mall landholders will be but a body of isolated units, having all the drawbacks of individualism and none of its virtues, unorganised and singularly ill-equipped for that great international struggle of our time, which we know as agricultural competition. $^{15}$

The concern for the 'men of small means' remained a feature of co-operative rhetoric throughout the early twentieth century. In a letter addressed to Fr Tom Finlay, the IAOS's vice-president, Plunkett argued that the early experience of the co-operative movement 'united men of the utmost diversity of position, circumstance, interest and opinion'. ${ }^{16}$ Ireland's ongoing transition from 'landlordism to a peasant proprietary' deprived them of a semblance of social cohesion. ${ }^{17}$ Co-operative organisations offered a means to create social cohesion and provided a platform for small farmers to contribute more effectively to national development. 
The emergence and growth of the co-operative movement within the Irish context occurred as an attempt to both stem the flow of outward rural migration and to marshal an efficient use of agricultural resources. A new caste of co-operative expert appeared in the countryside devoted to revolving issues around the production and distribution of agricultural goods, and in the process to establish a new form of political economy in Ireland. The cataclysmic shock of the Great Famine placed new pressures on Irish society that fundamentally shaped the emergent modern nation-state. Joseph Lee has argued that Irish modernisation, understood as a movement away from a peasant-based society resulted from slow improvements to farming, combined with concurrent processes of depopulation and infrastructural reform throughout the second half of the nineteenth century. ${ }^{18}$ The decades after the famine saw a growth in agricultural productivity caused by the decrease in the number of agricultural holdings smaller than one acre from 570,338 in 1851 to 485,455 in 1911 . This reduction in farmers cleared the land of smaller occupiers as reflected in the fact that the percentage of holdings under 15 acres dropped from 49 to 40 per cent in the same period. ${ }^{19}$ In the midst of the changes to land holding sizes and incremental increases in agricultural output, the interventions of organisers sent by the IAOS to visit farmers engaged in new co-operative businesses helped to develop new forms of agricultural knowledge from the 1890s onwards.

\section{An Irish economic revival}

The introduction of co-operative farming methods instigated by Plunkett in the 1890s happened as part of a wider process of cultural reconfiguration within Ireland. The Irish Revival of the late nineteenth century established a 'new "selfhelp" consensus' and provided space for new cultural projects to emerge. As Senia Paseta argues, the cultural revival's 'amorphousness' allowed it to be 'a rallying point for various political and social causes, and facilitated the fraternisation of individuals as diverse as Douglas Hyde, Eoin MacNeill, Horace Plunkett and George Russell'. ${ }^{20}$ At the same time, the Irish Revival benefited from the perceived irrelevance of constitutional politics. Irish nationalism lost momentum after the death of Charles Stewart Parnell and the consequent split in the IPP in the 1890 s. $^{21}$ The second Home Rule Bill's failure in 1893 side-lined the debate over Ireland's constitutional status. ${ }^{22}$ As a result, the cultural sphere provided the most dynamic arena in which to articulate Irish values and demonstrate the vitality of national life.

Rural co-operation provided the economic corollary to the new Irish dramatic, linguistic and sporting movements that emerged in the period. A plethora of cultural organisations sprang up that included W.B. Yeats's National Literary Society in 1892 and the Gaelic League by Douglas Hyde in 1893, which indicated support for Irish forms of cultural expression in the arts and language. ${ }^{23}$ 
These cultural initiatives coincided with the emergence of the new form of rural economics pioneered by Plunkett. Plunkett founded the IAOS in 1894 as a co-ordinating body to direct a fast-growing economic movement. The work of P.J. Mathews has made apparent the importance of mutual support that individuals from one revival movement offered to others. These revivalists shared an enthusiasm for a self-help ethos and a belief in the necessity for Irish modes of cultural, social and economic expression - as indicated by Plunkett's endorsement of the Gaelic League. ${ }^{24}$ In turn, support from literary quarters aided the initial growth of new co-operative societies as demonstrated by Lady Gregory's involvement in the successful effort to establish a co-operative society in her village. $^{25}$

Under Plunkett's stewardship, the co-operative movement galvanised enough support to drive the expansion of this project until it wove various social, economic and political threads together to create a distinct Irish culture. Stephen Gwynn later reflected upon the centrality of the economic aspect to the Revival, which proved decisive in the creation of Ireland's 'strong culture'. A former Nationalist MP, Gwynn identified many contributors to this cultural milieu which included the Gaelic League, the literary movement and Sinn Féin 'in its earlier more purely intellectual phase'. However, the most important social force that contributed to a modern Irish culture proved to be the co-operative movement:

All these separate activities were in touch with one another ... but Sir Horace Plunkett perhaps more than anyone else helped to create out of these a central culture. His wide sympathies drew about him a group of young men and women concerned generally for the welfare of Ireland... As a result, Irish thought began to be taken seriously wherever there was interest in ideas, and gained dignity in the process. ${ }^{26}$

Gwynn saw the co-operative movement as one significant network around which cultural and social expressions of Irishness cohered in the early twentieth century. Plunkett's effort to popularise co-operative solutions to rural problems fixated on the larger question of national character. The problems that afflicted Ireland also possessed a moral quality according to his analysis. The 'national habit of living in the past' only served to provide 'a present without achievement, a future without hope'. If the plays of literary revivalists were intended to stage new forms of Irishness for audiences to consume, then Plunkett hoped that the co-operative society might serve as a stage on which a new rural subjectivity could be performed. Writing fifteen years after the establishment of the first co-operative creamery, Plunkett admitted that:

The conclusion was long ago forced upon me that whatever may have been true of the past, the chief responsibility for the remoulding of our national life rests now with ourselves, and in the last analysis the problem of Irish ineffectiveness at home is in the main a problem of character - and of Irish character. ${ }^{27}$ 
The co-operative movement aimed at more than economic modernisation - it aimed to inculcate a new Irish subject characterised by a more co-operative outlook on social and political matters.

\section{Intellectual origins and early developments}

The agricultural co-operative movement that emerged in Ireland had complex and varied origins. Plunkett is recognised as the major conduit through which modern co-operative ideas as applied to agriculture came to Ireland. Plunkett proved to be a curious, outward-looking individual who saw the potential offered by the successful application of co-operative principles employed in other countries. Possessing the conviction of the convert, he yearned to replicate some of these effects in Ireland and his enthusiasm proved infectious as he recruited sympathetic support from a range of talented individuals. The dissemination and application of co-operation relied upon a network of supporters that increased and tied themselves to Plunkett's co-operative project. Without the assistance of Robert Anderson, the land agent from Cork, Fr T.A. Finlay the Jesuit economist, and George Russell (better known by his pen name $Æ$ ), along with the professional co-operative organisers who travelled the country, the spread of co-operation would have remained a sporadic isolated affair rather than the expansive network it grew into.

The history of co-operation in Ireland has a longer genealogy that predates the emergence of the agricultural co-operative movement in the 1880s. The continuation of some elements of a traditional farming system continued to exist well into the twentieth century. Folklorists and anthropologists identified a cooperative model of farming whereby the rural population shared in the performance of work across ties of family and kinship, although this communal form of labour, known as the meitheal, had been in decline since the Great Famine. ${ }^{28}$ More formalised co-operative experiments inspired by the ideas of Robert Owen also occurred in the early nineteenth century. During the 1830 s, co-operative retail societies appeared across Ulster; also in Ralahine, County Clare, a co-operative commune appeared on the Vandeleur estate. Individuals who supported Robert Owen's economic ideas founded these societies, but they failed to convert such enthusiasm into long-term success and within a few years, these experimental societies disappeared. ${ }^{29}$ Although their existence offered only minor inspiration for Plunkett and his group gathered around the IAOS, the Ralahine experiment provided inspiration for Irish socialists. James Connolly believed that the Ralahine experiment represented 'an Irish point of interrogation erected amidst the wilderness of capitalist thought and feudal practice'. In Connolly's 'rejuvenated Ireland of the future' Ralahine's peasants 'will be dwelt upon with admiration as a great and important landmark in the march of the human race towards its complete social emancipation'. ${ }^{30}$ Connolly's use of the Ralahine co-operative commune 
showed how co-operative ideas proved adaptable and ready to be championed by a diverse range of political and economic thinkers. This intellectual versatility proved to be one of factors behind the longevity of the co-operative ideal.

The modern Irish co-operative movement that grew out of the febrile cultural and intellectual atmosphere of the late nineteenth century drew upon co-operative precedents expressed elsewhere. This outside influence was crucial. The Danish uptake of creamery technology proved to be a formative example for Irish cooperators. Denmark's creamery sector grew rapidly in the 1880 s and this successful uptake was ascribed to the co-operative business model that aided this diffusion. Throughout the late nineteenth and early twentieth centuries, attempts to implant Danish innovations into the Irish context ensued as Irish agronomists, representatives from the co-operative movement and some politicians visited the dairying Valhalla. ${ }^{31}$ The Irish movement also looked to implant some of the continental advances in the field of co-operative finance to a cash-poor rural economy. The Raiffeisen co-operative rural banks established across Germany aimed to prevent small farmers prone to usurious practices from falling into a debt trap. Henry Wolff, the English expert on agricultural credit and a student of the Raiffeisen movement, proved to be a key expert in this field. Wolffs work popularised co-operative financial institutions across the English-speaking world. Plunkett read Wolff's People's Banks, and led the author to recount how 'having, as [Plunkett] put it - been "converted" by what I had written, in 1894 ... [he] invited me over to Dublin to "convert" his colleagues as well'. ${ }^{32}$

However, the presence of the Manchester-originated Co-operative Wholesale Society (CWS) in Ireland proved to be the most direct influence over Irish co-operative development. Close proximity and shared language enhanced the transfer of ideas in the short term. The CWS, established in 1863, formed a leading component of the British co-operative retail movement. The society acted as the primary wholesale agent for the movement and sold commodities to individual co-operative retail societies, which in turn sold on to their members primarily located in the urban centres throughout England. The purchase of foodstuffs formed the largest part of their business and the importance of items such as butter, eggs and other agricultural foodstuffs saw the CWS expand their presence across Ireland. The CWS opened large depots in Limerick, Armagh, Waterford, Tralee and Cork between 1868 and $1877 .{ }^{33}$ Furthermore, they employed their own agents in these towns in order to monitor and ensure the supply of foodstuffs.

The British co-operative movement's primary aim was to supply its industrial working-class membership base with high-quality, unadulterated foodstuffs at a cheap price. Securing a dependable supply of butter proved critical as it formed a staple part of the British diet. Irish dairy produce represented a propitious and important resource. In the mid-nineteenth century, unorganised dairy farmers supplied the CWS, which acquired Irish butter for its members living in industrial 
towns and cities. The CWS acquired a prominent position in the Irish dairy industry as it employed experienced buyers who attended the country's major butter markets and operated 'under the immediate and direct control of the Society - not merely being employed as agents or buyers on commission'. Their buyers took up residence close to the great butter markets in Ireland located primarily in the region of fertile dairy plains of south-west Ireland - Cork, Limerick and Tralee. ${ }^{34}$ As the CWS extended its presence in Ireland a British newspaper, the Co-operative News, summarised its spread as an attempt

to bring the producer and the consumer together, to so organise labour as to produce for known wants, and to serve the consumer as nearly as possible at cost price on condition that he finds the necessary capital in the first instead of the last instance ... It is really a find, and not an effort to him. ${ }^{35}$

Percy Redfern commented that the CWS 'grew fat on butter... [and] Ireland was the source of the supply'. The stated aim of the CWS, to harmonise the respective interests of consumer and producer, justified their initial extension into Ireland during the $1870 \mathrm{~s}^{36}$ The introduction of the creamery separator and competition from farmers in Denmark incentivised the CWS's greater involvement in the production process in order to benefit their membership base. Thus, the first co-operative creamery was organised on behalf of the CWS in Drumcollogher, County Limerick, in 1889. The principal figures behind its establishment were W.L. Stokes, who worked as the CWS's Limerick agent, and butter merchant, Robert Gibson. ${ }^{37}$ The CWS focused on securing the highest quality butter at the best possible price for the consumer. Although not its aim, the CWS played a crucial and controversial part in delineating a new variant of co-operative organisation that eventually took root in Ireland. When Plunkett and his followers began to organise their creameries during the 1890s, their focus on securing the highest price for the producer placed the two co-operative movements at philosophical odds.

When Horace Plunkett initiated his campaign to build a movement of rural co-operatives, it occurred within a broader international uptake of the co-operative model. In many ways, the adoption of co-operative organisation as a way to meet Irish farmers' social and economic challenges reflected the cosmopolitanism of the movement's founder. The modern co-operative principles that became rooted in the Irish movement had complex, international origins. Plunkett spent his young adult life conducting experiments in agricultural methods on the plains of Wyoming. ${ }^{38}$ Although initially living there for health reasons related to lung problems he spent time farming and conducting his own agronomical experiments. Plunkett returned to Ireland after his father's death in 1889 and quickly threw his energy behind the creation of a rural co-operative movement. Although not involved in the establishment of Ireland's first co-operative creamery, his interest in economic co-operation emerged at the same time. A diary entry dated 24 
January 1889 recorded a discussion on 'my co-operative hobby', but there is little evidence before this to suggest how he became attracted to the study of mutual economics. ${ }^{39}$

The successful example of co-operative stores in England piqued Plunkett's initial interest in co-operative economics. The formation of the Rochdale Equitable Pioneers Society in the north-west of England in 1844 represented a response to an economic depression. The Rochdale society served the working classes in an industrial cotton town that experienced a long-term downturn in living standards. This retail society marked a breakthrough in the modern co-operative movement. Other retail societies modelled on Rochdale were founded over the following years. The 'Rochdale Principles' also served as a template for other co-operatives that emerged around the globe in subsequent decades. At the heart of the modern co-operative model sat the democratic principle that entitled one member to one vote, irrespective of wealth, status or size of investment in the business. Open membership combined with political and religious tolerance formed another important feature of the model. ${ }^{40}$

The history of the co-operative movement in England raised the possibility that an opportunity existed to transplant the experiment in Ireland and animated Plunkett's first public intervention on the subject. In an article published in Nineteenth Century in 1888, he outlined the impoverished state of rural life and argued that the country's population 'are not able to obtain a fair exchange in commodities for what money they expend'. A solution that provided people access to reasonably priced goods required a form of social organisation such as 'the "Co-operative Store Society", an institution hitherto almost exclusively English. ${ }^{41}$ Fr Thomas Finlay SJ emphasised the importance of Plunkett's attendance at the 1889 Co-operative Congress in England, which allowed him to make 'a new and deeper study of the principles of co-operation, and [he] came back resolved to apply them on a large scale at home'. ${ }^{42}$ Plunkett attended the Congress at Ipswich where he 'met the leading men of the co-operative movement $\&$ at once plunged into co-operative thought'. ${ }^{43}$ After the first day of the conference, he recorded in his diary 'I was greatly impressed with the tone of the arguments used by the representatives of the working men ... I never before realised how much the working man is doing for himself compared with what is being done for him. ${ }^{44}$

The Ipswich Congress left an immediate impression with the young Irish reformer. Plunkett met and discussed co-operative principles with intellectual luminaries such as Alfred Marshall and Beatrice Potter. Enthused by the conversations that took place, Plunkett returned to Ireland with a plan. He travelled to Doneraile in County Cork that July, where he discussed with local dignitaries the new ideas he picked up and 'the feasibility of starting a cooperative movement in this district'. ${ }^{45}$ He returned in November along with J.C. Gray, who worked for the Co-operative Union, an organisation designed to promote co-operatives 
in all sectors of the economy. Plunkett's first foray in economic co-operation saw him attempt to transplant the consumer model adopted by the British co-operative movement. The proposed co-operative society was to be established along the lines of the English retail societies. He held two meetings at Doneraile courthouse on 21 November attended by a few local Protestants and some labourers, but without the support of local Catholic farmers and business, who Plunkett referred to as the 'R.C. squireens', which hinted at the future resistance efforts to establish co-operative societies would face. ${ }^{46}$ Doneraile Co-operative Society was established and affiliated to the Co-operative Union. Although an initial success, the society ceased trading as a co-operative after changes in management. Nevertheless, other local traders responded to the business through improved services and the experiment helped create a climate that led to the creation of the Doneraile Co-operative Credit Society in $1894 .^{47}$

Two important incidents occurred in Doneraile that influenced the development of the co-operative movement. First, Plunkett met a young land agent named Robert Anderson. Their mutual friend Alexis Roche introduced Anderson to Plunkett. In his memoir, Anderson recalled being 'abysmally ignorant of what a co-operative store was like or how it might succeed', but based on the meeting he offered to assist Plunkett in his new work. ${ }^{48}$ Anderson went on to forge a close working relationship with Plunkett throughout his life and served as the IAOS's first Secretary. Second, Plunkett's visit to the south-west of Ireland exposed him to the condition of the country's dairying heartlands. Anderson described this as the moment when Plunkett realised the problems that faced Irish dairying. Although then 'uninformed of the great revolution which had begun in Scandinavia, he divined the cause of the Irish dairying débacle and had designed a remedy for it'. The proximity of the CWS creamery in Drumcollogher awakened Plunkett's interest in the potential that co-operative creameries possessed for the improvement of rural Ireland and provided Plunkett with the raw material that became his 'more ambitious programme'. ${ }^{49}$ From this point onward, the creamery society became the primary vehicle for the expansion of Irish co-operation. As Plunkett's enthusiasm for the spread of creameries grew the example of Denmark moved evermore to the fore. In an address to the dairy farmers of Ireland, he cited Denmark as the important influence: 'To the organisation of Co-operative Creameries [in Ireland] is largely due the success of the Danish butter, the most formidable rival of our own product in the English markets. ${ }^{50}$

During 1890, Plunkett travelled throughout Ireland to encourage farmers to take on the responsibility of organising and administering their own creamery. On 28 April 1890, he drove with Anderson to Buttevant, County Cork, to convince the committee of a joint stock creamery, then in construction, to convert the business into a co-operative affair: 'Hard work. But the seed was sown, as the missionaries say. ${ }^{51}$ In these early years of organisation, the workload of promotion fell upon the shoulders of Plunkett and Anderson, as the pair visited districts 
across the country to address meetings of local farmers about the benefits attached to establishing their own creamery. Despite his 'halting delivery' the substance of his speeches remained 'admirable, clear, and logical' as he expanded upon co-operative principles and how they would be applied. Anderson in turn offered advice on how to arrange finance, milk payments and duties for the committee. ${ }^{52}$ Despite the limited resources at their disposal, the employment of a few organisers trained to conduct visits and expound on the virtue of co-operation did draw results. After five years, thirty-three co-operative dairy societies existed - all located in the dairying heartland of the south-west. ${ }^{53}$

\section{The Irish Agricultural Organisation Society}

The year 1894 remains a landmark year in the emergence of the modern Irish nation-state. The foundation of the IAOS saw an immediate professionalisation of efforts to reorganise rural society and spread the co-operative principle. The IAOS provided a locus of leadership for a growing movement of agricultural societies and proposed a direction for future growth informed by the study of co-operation in other countries. At the well-attended inaugural meeting held on the 18 April 1894 at the Antient Concert Rooms in Dublin, Plunkett addressed an audience drawn from a cross-section of influential Irish society: the Lord Mayor of Dublin; members of the Anglo-Irish gentry; leading industrialists and business people; and representatives from other state and voluntary organisations. Letters of support from the likes of the Catholic Archbishop of Dublin and Nationalist MPs signalled initial widespread support for the venture. Plunkett's speech that day offered a manifesto for rural renewal. He set out that the IAOS represented a 'new departure in the development of our national resources' - one which dealt directly 'only with the rural population of Ireland. I proceed upon the assumption that the chief wealth of Ireland thus limited is, and must ever be, almost agricultural.' Plunkett argued that agriculture could only achieve the necessary transformation if farmers acted in combination with one another. The influence of Scandinavia, Germany and Russia was highlighted as Plunkett emphasised that the IAOS looked to 'bring to the help of those whose life is passed in the quiet of the field the experience which belongs to wider opportunities of observation and a large acquaintance with commercial and industrial affairs'. ${ }^{54}$ The IAOS's role would be to act as an important conduit for new ideas and agricultural innovations between farmers and the outside world.

The IAOS played a crucial role in shaping the form of co-operation that spread across Ireland in the following years. The foothold made into the creamery industry in the first few years provided Plunkett and his supporters with strong evidence against the idea 'that farmers were incontrovertible atoms'. Instead, farmers were capable of communitarian organisation. The IAOS would facilitate this further act of combination through the employment of paid organisers whose 
job would be to visit co-operative societies 'and generally to instruct the farming community upon what can be done by co-operation'. ${ }^{5}$ Plunkett presided over the IAOS and Robert Anderson provided able administrative assistance as the Secretary. The Jesuit economist, Fr Thomas Finlay, joined the executive as VicePresident and offered the movement a public association with a leading intellectual voice from the Catholic Church. George William Russell, better known as Æ, joined the IAOS, first as an organiser, and worked as editor of the movement's weekly newspaper the Irish Homestead. The newspaper played an important role in the propagandist aspect of the IAOS and provided a forum for $\mathbb{E}-$ a polymath poet, theosophist and co-operative economist from Lurgan, County Armagh - to develop his own theories and practices of co-operative action for Ireland. The Homestead frequently published literary pieces that placed it firmly within the wider firmament of cultural revivalism. Most importantly, the newspaper circulated ideas about how to create a more co-operative economy, and debates of a social and political nature played out in its pages.

Organisation became the watchword of the co-operative movement and the IAOS acted as an important harbinger of Irish modernity as it strove to reorganise the countryside. The IAOS embarked upon the creation of a detailed study of the countryside as it strove to know as much about the rural population and its socio-economic conditions as possible. The IAOS's annual reports contained a reservoir of information related to each co-operative society. The publication of individual society accounts created a transparent audit of agricultural activity on a national level. These reports also included minutes of Annual General Meetings, membership figures for each society, and a statistical breakdown for co-operation in each county. ${ }^{56}$ The IAOS tracked social and economic trends affecting the produce that its members dealt in, which allowed organisers to provide precise instructions and market intelligence to help co-operative farmers prosper. In addition, the IAOS mapped and detailed an extraordinary amount of detail about economic activity across the countryside (see figure 1.1). Sat at the apex of a network of co-operative societies, the IAOS generated an insight into the condition of life, work and productivity, which could be used to direct targeted interventions towards individual societies when required. This information could also be utilised by government departments, which is what eventually occurred.

The co-operative movement asserted itself as a force for progress. The movement's leaders saw the IAOS as a means to 'fulfil their role as cultural and intellectual leaders'. One outcome of contemporary land reforms was that various social and cultural actors from Anglo-Irish backgrounds asserted their relevance as moral leaders in lieu of the connection between landlord and tenant that had prevailed in the nineteenth century. The IAOS represented one way in which a farmer might be morally reconstituted as a 'noble peasant of the cultural revival'.57 Plunkett's social status led to accusations that he served as a representative of the 


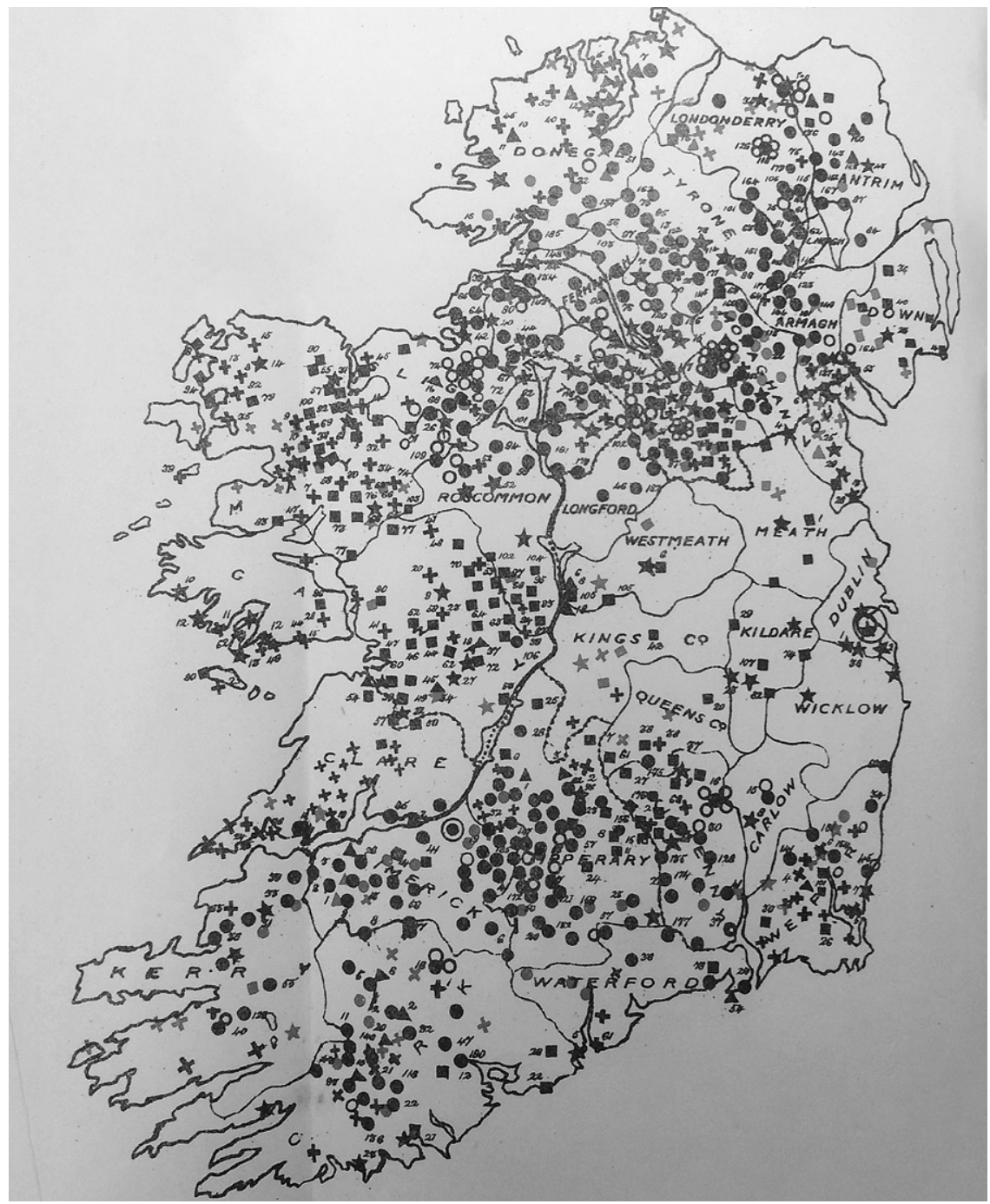

Figure 1.1 IAOS Co-operative network in 1902 Dairy and agricultural societies

Auxiliaries $\bigcirc$

Agricultural societies

Co-operative banks +

Poultry societies $\boldsymbol{\Delta}$

Miscellaneous $\star$

Federations $\bullet$

Societies registered prior to 31 December 1902 are printed in black.

Societies formed during 1903 are printed in grey. 
landlords in their attempt to assert moral leadership over farmers. Having Fr Thomas Finlay on side helped to counter criticisms from some nationalists that the IAOS represented a front for continuing traditional Anglo-Irish influence. Furthermore, members of the Catholic clergy helped to establish the co-operative movement at a local level. Parish priests and curates played an important brokerage role when they worked to create local support for a proposed creamery or credit society. In effect, the IAOS formed a site for a new co-operative élite to discuss the implications of its movement's project.

Keen observers of rural developments outside Ireland watched the unfolding agrarian experiment taking place with great interest. The IAOS represented one of the most prominent agrarian development organisations on the international stage at the start of the twentieth century - a point emphasised further by its almost unique stature within the Anglophone world. The attention and treatment given to questions of rural economy and agricultural modernisation meant that the Irish movement played a key role in influencing the establishment of similarly focused movements elsewhere. On the IAOS's twentieth anniversary, Horace Plunkett referred to the organisation as the 'parent' of similar bodies that had been founded in England and Scotland, as well as in the United States and Finland. ${ }^{58}$ Finnish farmers proved to be among the first of the new farmers' movements to take their lead from the Irish. The Pellervo Society, founded in 1899, drew heavily upon the precedent set by the IAOS, which its founding president, Hannes Gebhard, admitted to adopting as his model:

Co-operation in Ireland is of special interest for us, not only because the political position of that country and the poverty of its rural population resemble Finnish conditions, but principally for the reason that the origin and management of the co-operative movement there resemble more closely than those of any other country the origin and development of our own co-operation. ${ }^{59}$

The following year English agriculturalists established the Agricultural Organisation Society 'on the model of the Irish Agricultural Organisation Society', ${ }^{60}$ and a Scottish Agricultural Organisation Society followed in $1905 .^{61}$

The IAOS's organisational efforts quickly bore fruit as a sophisticated network of co-operative societies was established by the start of the twentieth century. The IAOS employed a small team of organisers who proved crucial to this process. These organisers' duties shifted from initial work mustering support for a potential society through to guiding the movement's wider development through policing societies. They regularly visited societies, assessed their output, and observed their adherence to IAOS rules. Organisers offered the following services: the provision of architectural and engineering advice; the provision of financial and accountkeeping expertise; identifying potential customers; and encouraged the diffusion of new technologies such as farm and dairy machinery. Organisers also attended 
local society Annual General Meetings and reported to Dublin on the spirit of co-operation throughout the districts. The establishment of a co-operative society encouraged dairy farmers to shed antiquated methods of production, and organisers reinforced ideal behaviours in order to nurture a co-operative population. When the IAOS expressed disquiet at the practice of creameries renewing informal loans to members, it fell to the organiser to discourage this behaviour. In 1907, for example, the IAOS emphasised that:

Every effort is being made by our Organisers to discourage this practice ... The uses and abuses of credit are being brought home to borrowers both at meetings of Societies, and through the Organisers' visits of inspection. ${ }^{62}$

The co-operative society had an innovative effect upon a local community, which was at once technological and democratic. Robert Anderson highlighted how a member's attendance at a society meeting made the movement's transformation instantly apparent. These meetings occurred against the backdrop of modern buildings that housed the new 'steam-driven separators, butter-workers, and churns, and all sorts of scientific appliances unavailable to the isolated farmer'. These rural enterprises were administered by a democratically elected committee, upon which 'the best business-men in the community' sat, whether 'landlord or tenant, Protestant or Roman Catholic, Unionist or Nationalist'. ${ }^{63}$ Often the presence of leading figures on these committees reflected an individual's status within a locality. However, the communal enterprise helped to introduce technological improvements to many localities through the collective purchase of machinery. Via the democratic process and governance structures in place, members theoretically could hold to account those who made business decisions.

Communication between the IAOS in Dublin and co-operative societies throughout Ireland formed a central feature of the strategy to nurture a modern countryside. The role of the IAOS organiser proved vital to the growth of the movement. The IAOS Secretary, Robert Anderson, recounted that his experience as an organiser consisted of long, strenuous days in order 'to bring unbelieving and tight-fisted farmers into the co-operative fold'. ${ }^{64}$ Organisers needed to convince an array of opponents that included shopkeepers, butter traders, private creamery owners and local politicians who viewed these new businesses as threats to their own interests. ${ }^{65}$ As a result, the organiser became the target of local opposition to the introduction of co-operative societies and meetings often descended into boisterous events. At one meeting in County Clare, Anderson recalled how he fled the village because of threats by local opponents to 'cut the "livers" out of him. ${ }^{66}$ As examined in later chapters various impediments stood between the IAOS's blueprint of a fully co-operative agricultural landscape and the reality of implementation. However, in the immediate aftermath of the IAOS's foundation the most potent threat to the continued existence of the Irish 
movement emanated from another source of co-operative organisational expertise the CWS.

\section{The Irish Agricultural Organisation Society and the Co-operative Wholesale Society}

The establishment of the IAOS in 1894 represented a seismic shift in the relationship between Irish and British co-operators. Its emergence challenged CWS interests in Ireland and offered an alternative paradigm for co-operative development. The CWS attempted to organise Irish farmers as suppliers to their cooperative depots and creameries with the objective of placing the interest of consumers above producers. Plunkett's effort to establish creameries at the end of the nineteenth century prioritised the interests and maximised the profits for the farmer. Plunkett described the IAOS's focus upon the producer as one of 'the newer tendencies in full work in this outpost of the co-operative world' ${ }^{67}$ It certainly represented one of the most prominent international producer cooperative movements in the early twentieth century. The IAOS capitalised upon the opportunity presented by the invention of creamery separators and sought to re-make the character of Irish farmers by providing access and ownership over this new technology. The CWS had acquiesced in its role as a butter buyer for most of the late nineteenth century. However, the modernisation of dairying combined with the IAOS's emergence as a new force in Irish dairying saw the CWS assume an enthusiasm for the creamery project and the potential for profit in butter manufacturing.

A vigorous debate about the future of co-operation in Ireland erupted within a year of the IAOS's establishment. As the IAOS and CWS began to organise creameries that placed different emphases on the interests of the farmers a flurry of correspondence on the issue about how best to organise a co-operative infrastructure over Irish butter production appeared in the pages of the Co-operative News. Henry Youngs, a correspondent from Norwich Co-operative Society in England, argued that 'it was the duty of the Wholesale Board ... to carry on the great work which it has in part proved itself so well able to do, not only in the collection and distributing of goods ... but in the production of same wherever possible when it is the advantage of its members' (emphasis added). He argued specifically in relation to the production of butter 'that if this policy is continued, not only in England but in Ireland we shall all as co-operators be benefitted'. A letter by Plunkett appeared alongside Youngs in which he offered an alternative view. Plunkett argued that the 'whole trouble between [the IAOS] and the Wholesale has ... arisen from the fact that co-operators do not understand farming, and the farming classes do not understand co-operation'. He highlighted the CWS's failure to organise any farming societies of their own in England as evidence of this fact. Plunkett believed the IAOS 'can solve this part of the 
co-operative problem'. However, he also warned that a rupture between the Irish and British movements appeared unavoidable

and if the spirit you arouse against us makes it better for us to sever our connection for a while with those who cannot trust us to look after the interests of co-operation in Ireland, I am confident that a few years will find English and Irish co-operators again joining hands across the Channel. ${ }^{68}$

As the IAOS and CWS championed their respective ideas for co-operative dairying, the strained relationship possessed important implications for the continued evolution of co-operation in Ireland that reflected an underlying tension between different co-operative organisations at the international level. In the late nineteenth century co-operative movements emerged across the globe to mediate economic effects upon consumers and producers. In 1895, the International Co-operative Alliance (ICA) was founded to co-ordinate the growth of these national movements. However, from the outset it was clear to onlookers that the CWS drove the direction of travel within this body. ${ }^{69}$ The French economist, Charles Gide, noted that agricultural and credit co-operatives, 'frightened by the imperialist ambitions of the consumers' societies, are gradually leaving the [International Co-operative] Alliance'. ${ }^{70}$ The IAOS chose to remain outside the ICA. Indeed, the Irish were not alone in this, as producer movements elsewhere failed to integrate into the international organisation. Owing to the ICA's focus on consumers' interests, Irish co-operators concluded that the pursuit of the farmers' interests required the movement to maintain a national focus. The proximity of the CWS more directly affected the IAOS's development as an attendant rivalry, hinted at on the level of international co-operative relations, played out vociferously in the south-west of Ireland.

In the earliest days of creamery organisation, the Irish organisers and the CWS seemingly worked in harmony as they looked to provide farmers with access to creamery separators and an improved product. Now, Irish co-operators retreated from a formal cross-movement alliance with British co-operators and focused more specifically on their movement within a national context. The difference over whether to prioritise the interests of the farmer or the consumer created a philosophical impasse that grew into an irresolvable economic conflict. Robert Anderson later described the resultant economic divergence that occurred in south-western Ireland as 'Civil War'. ${ }^{71}$ To dairy farmers, the CWS operated Irish creameries along similar lines to other privately operated creameries - that of an individual supplier to a business with little or no say over how the business was run. Critics held that the CWS encouraged a culture of dependency among Irish dairy farmers who relied upon milk payments from a CWS creamery committee, which they could not hold to account. This stood in stark contrast to farmers who supplied IAOS creameries. These farmers owned the creamery and shared in any profits. ${ }^{72}$ The IAOS aimed to safeguard its position as the most important 
instrument of co-operation in Ireland by exuding a popular appeal capable of countering the huge resources at the disposal of the CWS. The IAOS utilised one of its most potent tools - rhetoric. The agricultural co-operative movement claimed to work for the national interest and the fact the CWS originated from Manchester made it vulnerable to attack in a period of increased nationalistic sentiment. Described by one contemporary as 'avowedly non-political', the IAOS nevertheless employed the discursive tools of Irish nationalism to oust its competition. $^{73}$

Five of the CWS's six pre-1874 trade depots were located in the south-western province of Munster, which is where the economic conflict between the two co-operative bodies played out most viciously. The CWS expanded its size rapidly. In 1897, the CWS employed 91 employees throughout Ireland, of which 38 worked in the creameries. ${ }^{74}$ By 1900, 384 CWS employees worked in Ireland and its creameries accounted for 305 of this number. ${ }^{75}$ The CWS annual report for that year described the situation with satisfaction:

The Wholesale has now 35 creameries working, with 28 auxiliaries, chiefly in the south-western counties, and has been very successful in the attempt at butter-making. No expense was spared that the creameries might compete successfully with the well-equipped Danish creameries. ${ }^{76}$

The same report made no mention of the presence of IAOS creameries, which provided a closer competitor than the Danish creameries. By 1900 the number of IAOS creameries competing with the CWS stood at 153, with a further 38 auxiliary societies that captured milk supply from more remote farmers and which they then transported to a central society. ${ }^{77}$

By 1900, the CWS and IAOS were locked into an aggressive competition to organise the dairy industry. The Co-operative Congress, the conference held for all co-operative movements on the British Isles, endorsed the CWS's decision to establish its own creameries in Ireland. In response, the IAOS withdrew their representatives from the Co-operative Union - a body founded to co-ordinate the promotion of all co-operative societies. In August 1901, Plunkett used his address as that year's President of the National Co-operative Festival to justify this decision and their subsequent struggle to control the Irish creamery industry. In front of delegates gathered from across the United Kingdom, Plunkett argued that the British version of creamery organisation offered little in the way of the co-operative spirit when applied to Ireland. Co-operative principles needed to be judged by 'the effect which they produce upon the character of the individual and the extent to which they elevate the social and improve the material well-being of the community'. On this criterion, the CWS failed to apply co-operation in business with Irish farmers. The creameries operated by the CWS saw 'farmers supply their milk as they do to any other capitalist who gives them their price, but in which they have no share in either management or profit, in which they 
take no pride, in which they learn no lesson'. The Co-operative Congress's decision to endorse the extension of the CWS in the creamery industry forced the Irish movement into a position of 'co-operative Home Rule' ${ }^{78}$ The speech accused the CWS of failing to act in a co-operative fashion and publicly signalled the deterioration in relations between the Irish and British movements. The Co-operative News ran reports of Plunkett's speech 'on the trend of co-operation' as a 'criticism of the English Wholesale Society'. ${ }^{79}$ When he reflected on the speech, Plunkett admitted that "I "went for" the Wholesale Society and it appears that they so absolutely dominate the movement that I may have done so unwisely - perhaps I am in for a libel action'. ${ }^{80}$

The enmity provoked by the economic conflict between the two movements manifested at a local level. County Kerry represented a target area for co-operative extension as it possessed a 90 per cent rural population and formed an integral part of the dairying heartlands. ${ }^{81}$ In north Kerry, competition over the milk supply proved fierce, as the struggle to organise the region's dairying sector grew especially aggressive due to extra competition from a robust private creamery sector. However, the IAOS viewed the CWS creameries as the immediate threat due to their description as co-operative enterprises. Charles Riddall, the chief IAOS organiser for the south-west, found the majority of his workload for the 1900 s consisted of nullifying the threat posed by the CWS as each movement tried to squeeze the other organisation out of business. The CWS's venture into creamery ownership reached a peak in 1906 when relations between the two movements became critical. At this point, the CWS possessed 38 central creameries and 47 auxiliaries across Ireland, but mainly located in the province of Munster. Nine of these central creameries operated in County Kerry. ${ }^{82}$ The number of IAOS creameries continued to rise in the first decade of the twentieth century as it attempted to squeeze out the CWS. In 1900, only five creameries aligned to the Irish movement operated in County Kerry. By 1912, this number stood at 14 (see table 1.1). This seemed small when compared to the number of cooperative creameries in other counties. However, Kerry possessed a higher number of member-owners per society than any other co-operative creamery in Munster. In Kerry, the average number of members per society stood at 125 , while the provincial average was 71 .

How the co-operative principle ought to be applied to agriculture posed a specific iteration of the Irish Question - whether the principal subject to be considered in economic development plans should be the producer or the consumer. In August 1907 the Vice-President of the CWS, Thomas Tweddell, made his views on the matter clear in a paper entitled 'Co-operation of Consumers' delivered to a meeting of the British Association. Tweddell argued that the organisation of consumers represented the most beneficial form of co-operative organisation. Despite initially stating that time prevented him from concentrating upon cooperative production, Tweddell broke away from his putative subject to comment 
Table 1.1 Provincial statistics for IAOS creameries

\begin{tabular}{lccr}
\hline $\begin{array}{l}\text { Province } \\
\text { and county }\end{array}$ & $\begin{array}{l}\text { No. of IAOS } \\
\text { creameries }\end{array}$ & $\begin{array}{l}\text { No. of shareholders } \\
\text { on } 31 \text { December } \mathbf{1 9 1 2}\end{array}$ & Lbs. of butter made \\
\hline Clare & 1 & 99 & 74,306 \\
Cork & 21 & 876 & $1,589,479$ \\
Kerry & $\mathbf{1 4}$ & $\mathbf{1 , 7 4 9}$ & $\mathbf{2 , 3 6 3 , 7 9 9}$ \\
Limerick & 55 & 3,258 & $9,591,092$ \\
Tipperary & 51 & 4,150 & $6,719,417$ \\
Waterford & 2 & 128 & 151,576 \\
MUNSTER & $\mathbf{1 4 4}$ & $\mathbf{1 0 , 2 6 0}$ & $\mathbf{2 0 , 4 8 9 , 6 6 9}$ \\
\hline
\end{tabular}

Source: IAOS, Annual Report, 1913.

upon the Irish situation. The work of the CWS in pursuit of the consumers' interest placed the organisation firmly in a respected historical co-operative tradition as it represented 'Robert Owen's ideal, viz., the abolition of profit in all the wide ramifications of trade'. Tweddell considered it a misfortune, therefore, that instead of concentrating upon this work, their movement, 'should have spent so much of its time and energy in contending and disputing over it instead, but so it has been; this subject has been the Irish question of the Co-operative movement insoluble, interminable'. ${ }^{83}$

The 'interminable' aspect of this conflict emanated from the IAOS's implicit rejection of consumer-focused economics. The question of where the profits from the butter industry ended up remained a point of contention. One journalist for the Southern Star reported on the visit of a CWS deputation from Bristol to examine the butter industry of Ireland and its potential profitability. However, while the deputation enjoyed the profits, the journalist acerbically remarked that 'profits are always made out of somebody'. That 'somebody' included the farmers of counties Limerick, Cork and Kerry who supplied CWS creameries. The author resented the fact that that the CWS described itself as a 'co-operative' business in Ireland and stripped the farmer of profits he might otherwise hold if 'he worked the creamery as a real co-operative concern':

The fountain which gives forth bitter water as well as sweet is a less misleading institution than the 'co-operative' society which co-operates in Bristol to exploit in Kerry. The only claim the Wholesale has to be co-operative in Ireland is that it co-operates the potential profits of the farmer's industry away from him. ${ }^{84}$

By 1907, any possibility of détente between the Irish and British movements grew evermore distant. Knocknagoshel, a village just outside Tralee and close to the CWS depot, provided a practical example of the toxicity that characterised the relationship between the two organisations. That year, the IAOS applied 
pressure upon the CWS to relinquish control of its creamery in Knocknagoshel to local farmers. This accorded with previous claims by the CWS to relinquish ownership if local farmers demonstrated an appetite to operate their own business. ${ }^{85}$ Writing in the Irish Homestead, Æ argued that the farmers of Knocknagoshel enjoyed enough cross-community support to establish their own producer-oriented co-operative society, and lobbied the CWS to sell them the local creamery premises. However, the CWS demonstrated no desire to relinquish control. $Æ$ criticised the refusal to sell and branded the CWS as an organisation that, 'only took up the creamery business in Ireland because of the backward state of civilisation'. Æ understood the CWS's modernisation programme as one defined in opposition to the rural project undertaken by the IAOS. He acidly argued that conditions in Kerry showed that 'civilisation is not in such a backward state ... and that the creamery might safely be sold to the local farmers without their lapsing back into barbarism'. Furthermore, the dispute at Knocknagoshel allowed $Æ$ to define the CWS as a usurious presence in Ireland: 'Their game - let us put it plainly - has been in Ireland the game played by any gombeen trader, who lets his customers have credit so that they may remain on his books' ${ }^{86}$

By likening the CWS to traditional enemies of farmers - private interests, publicans and gombeen men - and combining this with their status as an exploiter of Irish producers, $Æ$ and the IAOS crafted a powerful discourse that tapped into popular sentiment that undermined the popular appeal of the CWS. Furthermore, $Æ$ located his attack within a language of nationalism, accusing the CWS of pursuing the 'bondage' of Irish farmers so that 'the English working man may get cheaper butter at our expense'. ${ }^{87}$ This binary of producer and consumer helped co-operators define their early twentieth-century Irish subject as something antithetical from the (English) consumer.

IAOS organisers utilised similar arguments to extend their movement's appeal at a local level. In 1907, local farmers had lobbied the Rural District Council to promote a co-operative bacon-curing plant in the north Kerry market town of Listowel in order 'to divert some of the big profits of the Bacon trade here from three or four large firms, into the hands of the producers - the farmers and labourers - and to give employment ${ }^{88}$ In the end, the plant never materialised due to opposition and in spite of support given by Horace Plunkett. ${ }^{89}$ In December 1908, Charles Riddall arrived in Listowel to persuade locals of the benefits of organising their own creamery along IAOS-oriented lines. The local newspaper recorded Riddall's speech to the farmers around Listowel, which made a scathing attack upon the CWS:

This English Co-operative Society was ... thoroughly co-operative in England, but in Ireland it stood on the very same level as a proprietary creamery. In Knocknagoshel, one of the principal points to be got over in regard to the people's connection with the English concern was the fact that the farmers ... were tied hand and foot in the English institution, and it then became the task of farmers in that locality to 
liberate themselves from the hands of those English persons who came over to Ireland some twenty years ago posing ... in many cases as philanthropists, but who had proved to be in many cases the exact opposite. ${ }^{90}$

This verbal assault sounded the decline of the CWS's efforts to organise Irish dairying.

In January 1909, the CWS ceded the co-operative territory around creameries to the IAOS, having shared 'the common experience of those Englishmen who seek to pave the bogs of Ireland with good intentions'. ${ }^{91}$ By the end of that decade, the CWS ceased establishing creameries and sold off most of its concerns to local farmers or creamery proprietors retaining only three creameries and six auxiliaries. ${ }^{92}$ In Knocknagoshel, farmers assumed control of the local creamery premises. Riddall argued that the prosperity of Irish farmers relied upon their 'liberation' from an English institution, thereby linking the IAOS and co-operative farmers in Kerry to larger processes of social change and intensified nationalism that underpinned this period. The outcome of this conflict held important consequences for the continued development of co-operative organisation in Ireland. The IAOS became bound up within economic debates about what direction to take national development. The idealisation of the Irish producer as opposed to the British consumer affected not only the development of the Irish co-operative movement, but also the entire socio-economic development of Ireland.

Throughout the 1890s, the CWS established creameries in Ireland that privileged the interests of consumer-members over those of farmer-producers. Percy Redfern, the CWS's official historian, wrote in 1913 in summation of this situation that 'the CWS sought to provide the English co-operative consumer with a British-made alternative equal in quality to Danish butter'. By establishing creameries in Ireland, the CWS hoped to become less reliant on purchasing highly priced butter from Denmark through the organisation and control of the means of production in Ireland. Such a policy, the IAOS maintained, did not serve the interests of their members. In a sign that the competition between the CWS and the IAOS still rankled, Redfern characterised the IAOS position as one in which:

The [CWS] was charged with desiring to make of the Irish 'a stick to beat the

Danes.' Irishmen have not the character of being averse to sticks and beatings, but in this case they wanted for themselves as producers the full rewards of victory. ${ }^{93}$

Throughout the early twentieth century, the co-operative movement played a prominent role in the conception and definition of the Irish nation - in particular the economics of the Irish nation. The crucial outcome in the economic war between the CWS and the IAOS resided in the fact that in championing its own model of economic co-operation, the IAOS made the Irish farmer-producer the central economic unit of its plans for co-operative development. Moreover, the economic arguments made by IAOS employees fed into a wider nationalist 
critique that existed outside the traditional forums of parliamentary debates around Home Rule and political autonomy. As shown in their speeches, Irish co-operative organisers frequently deployed a nationalist-infused rhetoric when they appealed to farmers to establish a co-operative society along the IAOS principle rather than the CWS. As the two co-operative organisations strove for dominance of the creamery sector, the IAOS's support for rural producers led to a differentiation in Irish and English identities primarily articulated in the sphere of economics. The efforts to establish itself as the pre-eminent co-operative movement among the Irish farmers proved to be a time-consuming and costly challenge for the IAOS in its formative years. However, it faced many other challenges to promote its co-operative movement across rural Ireland - but despite this the IAOS also managed to build an institutional legacy that helped to establish a long-term developmental plan for a new and modern Ireland.

\section{Notes}

1 Horace Plunkett, 'The Irish Agricultural Organisation Society, Limited - What it is and What it Does', in Irish Agricultural Organisation Society, Annual Report, 1895 (Dublin: Sealy, Bryers and Walker, 1895), 17-18 (p. 17).

2 James C. Scott, Seeing Like a State: How Certain Schemes to Improve the Human Condition Have Failed (London: Yale University Press, 1998).

3 Horace Plunkett, Ireland in the New Century: with an Epilogue in Answer to Some Critics (London: John Murray, 1905), 40-41.

4 Plunkett, Ireland in the New Century, 44-45.

5 Mary E. Daly, The Famine in Ireland (Dundalk: Dundalgen Press, 1986); James S. Donnelly, Jr, The Great Irish Potato Famine (Stroud: Sutton, 2001). Cormac Ó Gráda, Black '47 and Beyond: The Great Irish Famine in History, Economy, and Memory (Princeton: Princeton University Press, 1999).

6 K. Theodore Hoppen, Governing Hibernia: British Politicians and Ireland 1800-1921 (Oxford: Oxford University Press, 2016), 128.

7 Enda Delaney, 'Our Island Story? Towards a Transnational History of Late Modern Ireland', Irish Historical Studies, 37 (2011), 599-621 (pp. 601-602).

8 Sarah Roddy, Population, Providence and Empire: The Churches and Emigration from Nineteenth-Century Ireland (Manchester: Manchester University Press, 2014).

9 Barbara Lewis Solow, The Land Question and the Irish Economy (Cambridge, Mass.: Harvard University Press, 1971), 171-173.

10 Joanna Bourke, Husbandry to Housewifery: Women, Economic Change and Housework in Ireland, 1890-1914 (Oxford: Clarendon Press, 1993), 85.

11 Kevin O’Rourke, 'Property Rights, Politics and Innovation: Creamery Diffusion in pre-1914 Ireland', European Review of Economic History, 11 (2007), 395-417.

12 Ingrid Henriksen, 'Avoiding Lock-In: Co-operative Creameries in Denmark, 1882-1903', European Review of Economic History, 3.1 (1999), 57-78; Ingrid Henriksen and Kevin H. O'Rourke, 'Incentives, Technology and the Shift to Year-Round Dairying in Late Nineteenth Century Denmark', Economic History Review, 58.3 (2005), 520-554. 
Cormac Ó Gráda, Ireland: A New Economic History, 1780-1939 (Oxford: Clarendon Press, 1994), 259-262.

13 Hoppen, Governing Hibernia, 219-222; Virginia Crossman, Politics, Pauperism and Power in Late Nineteenth-Century Ireland (Manchester: Manchester University Press, 2006); Ó Gráda, Black ' 47 and Beyond, 104-114.

14 Terence Dooley, 'Land and Politics in Independent Ireland, 1923-1948: The Case for Reappraisal', Irish Historical Studies, 34.134 (2004), 175-197; Dooley, 'The Land for the People: The Land Question in Independent Ireland (Dublin: University College Dublin Press, 2004).

15 Plunkett, Ireland in the New Century, 44.

16 NLI, Ms 49,803/44/2, Horace Plunkett to Fr Finlay, December 1909,

17 Plunkett, Ireland in the New Century, 44.

18 Joseph Lee, The Modernisation of Irish Society, 1848-1918, 3rd edn (Dublin: Gill \& Macmillan, 2008).

19 Ó Gráda, Ireland: A New Economic History, 259.

20 Senia Paseta, Before the Revolution: Nationalism, Social Change and Ireland's Catholic Elite, 1879-1922 (Cork: Cork University Press, 1999), 153.

21 Paul Bew, Enigma: A New Life of Charles Stewart Parnell (Dublin: Gill \& Macmillan, 2012), chapters 6 and 7.

22 Alvin Jackson, Home Rule: An Irish History, 1800-2000 (Oxford: Oxford University Press, 2003), 80-85.

23 P.J. Mathews, Revival: the Abbey Theatre, Sinn Féin, the Gaelic League and the Co-operative Movement (Cork: Cork University Press, 2003).

24 Mathews, Revival, p. 30.

25 Augusta Gregory, 'Ireland, Real and Ideal', Nineteenth Century, 44.261 (1898), 769-782 (pp. 771-773); Mathews, Revival, p. 5; John Hutchinson, The Dynamics of Cultural Nationalism: The Gaelic Revival and the Creation of the Irish Nation State (London: Allen \& Unwin, 1987).

26 Stephen Gwynn, Ireland (London: Ernest Benn, 1924), 118-119.

27 Plunkett, Ireland in the New Century, p. 32.

28 Conrad M. Arensberg, The Irish Countryman, 2nd edn (Garden City, New York: Natural History Press, 1968); Conrad Arensberg and Solon T. Kimball, Family and Community in Ireland, 2nd edn (Gloucester, Massachusetts: Peter Smith, 1961); Anne O'Dowd, Meitheal: A Study of Co-operative Rural Labour (Dublin: Comhairle Bhéaloideas Éireann, 1981); Breandán Mac Suibhne, The End of Outrage: Post-Famine Adjustment in Rural Ireland (Oxford: Oxford University Press, 2017), 97-98.

29 Vincent Geoghegan, 'Robert Owen, Co-operation and Ulster in the 1830s', in Politics and the Irish Working Class, 1830-1945 (Houndmills, Basingstoke: Palgrave Macmillan, 2005), 6-26; E.T. Craig, An Irish Commune: The History of Ralahine (Dublin: M. Lester, 1920).

30 James Connolly, Labour in Ireland: Labour in Irish History; The Re-conquest of Ireland (Dublin: Maunsel \& Roberts Ltd, 1922), 143.

31 Henriksen, 'Avoiding Lock-In'; Thomas O'Donnell, A Trip to Denmark (Dublin: Gill \& Macmillan, 1908); Ó Gráda, Ireland, 259-262.

32 Henry W. Wolff, People's Banks: A Record of Social and Economic Success, 3rd edn (London: P.S. King and Son, 1910 [1893]), 558. 
33 Anthony Webster, 'Building the Wholesale: The Development of the English CWS and British Co-operative Business 1863-90', Business History, 54.6 (2012), 883-904.

34 CWS, Annual 1897 (Manchester: CWS, 1897), 16.

35 Co-operative News, 23 May 1874, cited in Percy Redfern, The Story of the CWS: The Jubilee History of the Co-operative Wholesale Society Limited. 1863-1913 (Manchester: CWS, 1913), 95.

36 Redfern, Story of the CWS, 95-96.

37 Carla King, 'The Early Development of Agricultural Co-operation: Some French and Irish Comparisons', in Proceedings of the Royal Irish Academy: Archaeology, Culture, History, Literature, 96C. 3 (1996), 67-86 (p. 70).

38 Lawrence M. Woods, Horace Plunkett in America: An Irish Aristocrat on the Wyoming Range (Norman, Oklahoma: Arthur H. Clarke Co., 2010).

39 NLI, Horace Plunkett Diary, 24 January 1889.

40 John F. Wilson, Anthony Webster and Rachel Vorberg-Rugh, Building Co-operation: A Business History of the Co-operative Group, 1863-2013 (Oxford: Oxford University Press, 2013), 34-42.

41 Horace Curzon Plunkett, 'Co-operative Stores for Ireland', Nineteenth Century, 24.139 (1888), 410-418 (p. 411).

42 T.A. Finlay, 'Agricultural Co-operation in Ireland', Economic Journal, 6.22 (1896), 204-211 (p. 205).

43 Horace Plunkett Diary, 9 June 1889.

44 Horace Plunkett Diary, 10 June 1889.

45 Horace Plunkett Diary, 18 July 1889.

46 Horace Plunkett Diary, 21 November 1889.

47 Patrick Bolger, The Irish Co-operative Movement: Its History and Development (Dublin: Institute of Public Administration, 1977), 59.

48 R.A. Anderson, With Horace Plunkett in Ireland: The Co-op Organisers' Story (London: Macmillan and Co., 1935), 1-2.

49 Anderson, With Horace Plunkett, 6-7.

50 Horace Curzon Plunkett, Co-operative Dairying: an Address to the Farmers of the Dairy Districts of Ireland (Manchester: Co-operative Union Limited, 1890), 6-7.

51 Horace Plunkett Diary, 28 April 1890.

52 Anderson, With Horace Plunkett, 12.

53 IAOS, Annual Report, 1895 (Dublin: Sealy, Bryers and Walker), 11.

54 'Irish Agricultural Organisation Society', Irish Times, 19 April 1894, 5.

55 Horace Plunkett, 'The Aims of the Co-operative Movement (1894)', in Declan Kiberd and P.J. Mathews (eds), Handbook of the Irish Revival: An Anthology of Irish Cultural and Political Writings 1891-1922 (Dublin: Abbey Theatre Press, 2015), 90.

56 For example see, IAOS, Annual Report, 1914, appendices.

57 Leeann Lane, "It is in the Cottages and Farmers' Houses that the Nation is Born": Æ's "Irish Homestead” and the Cultural Revival', Irish University Review, 33.1 (2003), 165-181 (p. 167).

58 Irish Agricultural Organisation Society, Report of the Irish Agricultural Organisation Society for the period from 1st July 1914 to the 31st March 1915 (Dublin: The Sackville Press, 1916), 40. 
59 Hannes Gebhard, Co-operation in Finland (London: Williams and Norgate, 1916), 35.

60 'Agricultural Reform', Co-operative News, 19 May 1900, 507.

61 John Morley, British Agricultural Co-operatives (London: Hutchinson Bentham, 1975), 20-22; Malcolm Sargent, Agricultural Co-operation (Aldershot, Hampshire: Gower, 1982), 18-19.

62 IAOS, Annual Report, 1907, 8-9.

63 R.A. Anderson, 'Agricultural Co-operation in Ireland', in Ireland: Industrial and Agricultural, ed. by Department of Agriculture and Technical Instruction (Dublin: Brown and Nolan, Limited, 1902), 218-234 (p. 232).

64 Anderson, With Horace Plunkett, 30.

65 Líam Kennedy, 'Farmers, Traders and Agricultural Politics in Pre-Independence Ireland', in Irish Peasants: Violence and Political Unrest, 1780-1914, ed. by James S. Donnelly Jr and Samuel Clark (Manchester: Manchester University Press, 1983), 339-373.

66 Anderson, With Horace Plunkett, 20.

67 Anderson, 'Agricultural Co-operation', 232.

68 Henry Youngs and Horace Plunkett, 'The Wholesale and Irish Agricultural Organisation Society', Co-operative News, 29 June 1895, 695-697.

69 Johnston Birchall, The International Co-operative Movement (Manchester: Manchester University Press, 1997).

70 Charles Gide, Consumers' Co-operative Societies (Manchester: Co-operative Union Limited, 1921), 140.

71 Anderson, With Horace Plunkett, 76-85.

72 Louis P.F. Smith, The Evolution of Agricultural Co-operation (Oxford: Blackwell, 1961), 195.

73 Stephen Gwynn, The History of Ireland (New York: The Macmillan Company, 1923), 492.

74 CWS, Annual Report, 1899 (Manchester: CWS, 1897), 7.

75 CWS, Annual Report, 1900 (Manchester: CWS, 1900), 7.

76 CWS, Annual Report, 1900, 16.

77 IAOS, Annual Report, 1899 (Dublin: Sealy, Bryers and Walker, 1899), 9.

78 Horace Plunkett, The Trend of Co-operation in Great Britain and Ireland (Dublin; n.p., 1902), 3, 13.

79 'National Co-operative Festival', Co-operative News, 24 August 1901, 1023-1024.

80 Horace Plunkett Diary, 16 August 1901.

81 Desmond A. Gillmor, 'Agriculture', Irish Resources and Land Use, ed. by D.A. Gillmor (Dublin: Institute of Public Administration, 1979), 109-137 (pp. 119-122); Desmond Gillmor, 'Land and People, c.1926', in A New History of Ireland, Volume VII: Ireland, 1921-84, ed. by J.R. Hill (Oxford: Oxford University Press, 2003), 62-85 (p. 84).

82 CWS, Annual 1906 (Manchester: CWS, 1906), 3.

83 CWS, Annual 1908 (Manchester: CWS, 1908), 140.

84 'Practical Farming: The Profits of Butter-making', Southern Star, 4 August 1906, 3.

85 CWS, Report and Balance Sheet for Half Year Ending June 1903 (Manchester: Cooperative Union, 1903). 
86 'Gombeen' is a pejorative term that referred to an individual who made money at other people's expense and misfortune. The term possessed usurious overtones and co-operators applied the term to economic rivals. Peter Gibbon and M.D. Higgins, 'Patronage, Tradition and Modernisation: The Case of the Irish "Gombeenman"', Economic and Social Review, 6.1 (1974), 27-44.

87 'Why the Traders Leave the CWS Alone', Irish Homestead, 19 January 1907.

88 Kerry Local History Archive (KLHA), Minute Book of Listowel District, Rural District Council, 'Proposed Co-operative Bacon Curing Plant', 31 October 1907.

89 'The Co-operative Movement in North Kerry: The Proposed Bacon Factory', Kerry Sentinel, 22 February 1908.

90 'Proposed Co-operative Creamery for Listowel', Kerry Sentinel, 2 December 1908.

91 Redfern, Story of the CWS, 303.

92 Bolger, The Irish Co-operative Movement, 198.

93 Redfern, Story of the CWS, 296. 